\title{
Pengaruh Pemanfaatan Media Lingkungan Sebagai Sumber Belajar Terhadap Hasil Belajar Mata Pelajaran IPA Di Madrasah Ibtidaiyah
}

Rosa Fadhilah Sari ${ }^{1}$, Muhamad Afandi ${ }^{2}$, Kms. Mas'ud Ali ${ }^{3}$

123 Islamic Statate University of Raden Fatah Palembang, Indonesia

\begin{tabular}{|c|c|}
\hline (A) Check for updates open $\partial_{\text {access }}$ c) (1) (2) & DOI : 10.47400/jiees.v1i2.19 \\
\hline Sections Info & BSTRACT (9 pt) \\
\hline $\begin{array}{l}\text { Article history: } \\
\text { Received: Oktober } 282020 \\
\text { Accepted: Oktober } 302020 \\
\text { Published online: Desember } 30 \\
2020\end{array}$ & $\begin{array}{l}\text { The purpose of this study was to determine the effect of the use of environmental media } \\
\text { as a learning resource on the learning outcomes of class III science subjects at MI Al- } \\
\text { Amalul Khair Palembang. This type of research is quantitative research with experimental } \\
\text { methods and a one group pretest-posttest design research design. The data collection } \\
\text { techniques used in this study were tests and documentation. While the data analysis }\end{array}$ \\
\hline $\begin{array}{l}\text { Keywords: } \\
\text { learning outcomes, } \\
\text { science, } \\
\text { environment, } \\
\text { media, } \\
\text { learning resources }\end{array}$ & $\begin{array}{l}<0.05 \text { and the } t \text { count is } 10.617 \text {, which is greater than the t table at the } 5 \% \text { level, namely } \\
\text { 1.699. The results of this data analysis indicate that Ho is rejected and } \mathrm{Ha} \text { is accepted, } \\
\text { which means that there is an influence between the pretest and posttest. So it can be } \\
\text { concluded that there is an effect of the use of environmental media as a learning resource } \\
\text { on the learning outcomes of class III science subjects at MI Al-Amalul Khair Palembang.. }\end{array}$ \\
\hline
\end{tabular}

\section{INTRODUCTION}

Lingkungan adalah situasi di sekitar proses belajar-mengajar terjadi (Sangidun, 2010: 11). Lingkungan sekitar merupakan sarana bagi peserta didik, dimana peserta didik dapat beraktivitas, berekreasi, berinovasi, termasuk mengembangkan pikiran sehingga membentuk perilaku baru dalam kegiatannya. Dengan kata lain lingkungan dapat dijadikan sebagai "laboratorium" atau tempat bagi peserta didik untuk bereksplorasi, bereksperimen, dan mengekspresikan diri untuk mendapatkan konsep dan informasi baru sebagai wujud dari hasil belajar (Mariyana, 2010: 17). Lingkungan merupakan wadah tempat peserta didik dapat mengungkapkan seluruh pikiran dan kegiatannya dalam proses pembelajaran.

Lingkungan adalah contoh nyata dalam sebuah pembelajaran, terutama dalam pembelajaran IPA. Lingkungan dapat mengenalkan secara langsung kepada peserta didik mengenai fenomena, bentuk, gerak, sehingga peserta didik memperoleh contoh yang kongkrit dalam proses pembelajaran, salah satu lingkungan yang dapat dimanfaatkan sebagai sumber belajar adalah lingkungan sekolah. Lingkungan merupakan sumber belajar yang paling efektif dan efesien serta tidak membutuhkan biaya yang besar dalam meningkatkan hasil belajar peserta didik, serta dapat digunakan secara sendiri-sendiri maupun secara kelompok.

Sumber belajar merupakan alat bantu yang berguna dalam kegiatan belajarmengajar seperti bahan-bahan yang dimanfaatkan dan diperlukan dalam proses pembelajaran, yang dapat berupa buku teks, media cetak, media elektronik, nara sumber, lingkungan sekitar dan sebagainya yang dapat meningkatkan gairah belajar bagi peserta didik (Djamarah dan Zain, 1997: 3). Assosiasi Teknologi Komunikasi Pendidikan (AECT) mendefinisikan sumber belajar adalah berbagai atau semua sumber baik yang berupa data, orang dan wujud tertentu yang dapat digunakan oleh peserta didik dalam belajar baik secara terpisah maupun secara terkombinasi, sehingga mempermudah peserta didik dalam mencapai tujuan belajarnya (Daryanto, 2010: 60). 
Oleh karena itu, sumber belajar adalah semua komponen sistem instruksional baik yang secara khusus dirancang maupun yang menurut sifatnya dapat dipakai atau dimanfaatkan dalam kegiatan pembelajaran. Adapun menurut Banks (Komalasari, 2010: 56) dalam Komalasari, sumber belajar adalah segala sesuatu atau daya yang dapat dimanfaatkan oleh guru, baik secara terpisah maupun dalam bentuk gabungan untuk kepentingan belajar mengajar dengan tujuan meningkatkan efektivitas dan effesiensi tujuan pembelajaran.

Sumber belajar merupakan komponen yang sangat penting untuk keberhasilan suatu proses pembelajaran. Oleh karena itu, seorang guru harus menyiapkan sumber belajar untuk membantu peserta didik supaya dapat memahami materi yang disampaikan dan pendidik juga harus tahu karakteristik setiap peserta didik agar dapat menciptakan suasana pembelajaran yang menyenangkan dan menantang artinya dalam pelaksanaan pembelajaran peserta didik harus dibawa pada kondisi yang menyenangkan dan menantang bagi dirinya, seperti membawa peserta didik keluar ruangan dan mengajaknya belajar di lingkungan sekolah tapi disesuaikan dengan mata pelajaran dan materinya. Belajar yang menyenangkan bukan berarti harus berteriakteriak dan menimbulkan kegaduhan. Akan tetapi, menyenangkan dimaknai pembelajaran harus menarik bagi peserta didik sehingga anak akan merasa tertarik dan tertantang untuk mengikuti serangkai pembelajaran yang dirancang oleh guru. Sesulit apa pun materi pembelajaran, jika disampaikan dengan menyenangkan peserta didik akan mampu memahaminya. Jadi, lingkungan sebagai sumber belajar adalah anak didik belajar langsung dengan menggunakan lingkungan sekitar yang anak didiknya dapat melihat langsung kejadian-kejadian di alam sekitar. Sumber belajar lingkungan ini akan semakin memperkaya wawasan dan pengetahuan anak karena mereka belajar tidak terbatas oleh tempat dan dinding kelas. Selain itu kebenarannya juga akurat, sebab anak dapat melihat secara langsung.

Pendidikan berkualitas dalam proses pembelajarannya pasti memperhatikan unsur-unsur yang mendukung diantaranya media sebagai sarana penyampai materi yang tidak bisa terlepas dari strategi, metode, teknik, dan media pembelajaran (Rasiman, dkk., 2020). Pemanfaatan lingkungan sebagai media dan juga sebagai sumber belajar dapat digunakan untuk meningkatkan mutu dan kualitas proses pembelajaran. Hal ini ditunjukkan dari hasil penelitian Hendarwati (2014) yang menunjukkan bahwa pemanfaatan lingkungan sebagai sumber belajar dapat meningkatkan hasil belajar peserta didik. Selain itu melalui pemanfaatan lingkungan sebagai sumber belajar juga dapat meningkatkan kemampuan penguasaan konsep, aktivitas belajar dan juga melatih kemampuan berpikir kritis peserta didik (Ramawati, 2016; Istiani dan Retnoningsih, 2015; Khanifah, Pukan, dan Sukaesih, 2012; Mahkota, Jalmo, dan Yolida, 2014).

Menurut Samatowa (2011: 22), mata pelajaran yang berhubungan erat dengan lingkungan yaitu IPA dengan memanfaatkan lingkungan sekitar merupakan cara yang efektif untuk memusatkan perhatian peserta didik pada saat berlangsung proses pembelajaran, mengkongretkan informasi dan merupakan sumber belajar yang tidak ada habisnya. Trianto dalam Samatowa (2007: 136), mengatakan bahwa IPA adalah suatu kumpulan teori yang sistematis, penerapannya secara umum terbatas pada gejala- gejala alam, lahir dan berkembang melalui metode ilmiah seperti observasi dan 
eksperimen serta melibatkan keaktifan belajar. IPA merupakan ilmu pengetahuan yang mencari tahu tentang alam secara sistematis, sehingga IPA bukan hanya penguasaan kumpulan pengetahuan yang berupa fakta-fakta, konsep-konsep atau prinsip-prinsip saja, tetapi merupakan suatu proses penemuan. Proses pembelajaran IPA menekankan pada pemberian pengalaman secara langsung untuk mengembangkan kompetensi peserta didik agar menjelajahi dan memahami alam secara ilmiah (Fatoni, 2012: 11).

IPA dipandang sebagai faktor yang mengubah sikap dan pandangan manusia terhadap alam semesta yaitu dari sudut pandang mitologi menjadi sikap ilmiah. Dengan tersedianya sumber belajar di lingkungan sekolah, memungkinkan peserta didik untuk menggali lebih dalam sumber daya yang terdapat di daerahnya. Peserta didik dapat memahami potensi dan sumber daya yang tersedia di sekitarnya. Selain itu metode ini dapat membantu peserta didik dalam rangka menyatukan peserta didik dengan lingkungan sekitar. Peserta didik dapat lebih peka untuk melestarikan lingkungan sekitarnya. Metode ini juga dapat membantu peserta didik lebih dekat mengenal lingkungan, sehingga memudahkan peserta didik bersosialisasi dengan baik terhadap sekitarnya. Untuk materi yang digunakan peneliti menggunakan materi lingkungan sehat dan lingkungan tidak sehat agar peserta didik dapat mengetahui dan memahami baik secara pengetahuan maupun secara langsung.

\section{RESEARCH METHOD}

Penelitian ini dilaksanakan di MI Al-Amalul Khoir Palembang berdiri pada tahun 2004 yang berlokasi di Jalan Lunjuk Jaya Bukit Besar, Kel. Lorok Pakjo 30137, Kec. Ilir Barat I, Kota Palembang. Jenis penelitian ini adalah penelitian kuantitatif dengan menggunakan metode eksperimen dan desain penelitian one grup pretest-posttest design yaitu menggunakan satu kelompok subjek. Adapun populasi dalam penelitian ini adalah peserta didik Madrasah Ibtidaiyah Al-Amalul Khair Palembang di kelas III B yang berjumlah 30 orang peserta didik. Sampel penelitian menggunakan sampel jenuh atau seluruh populasi penelitian digunakan dalam sampel penelitian. Teknik pengumpulan menggunakan tes dan dokumentasi. Teknik analisis data melalui: (1) uji pra-penelitian: uji validitas dan uji reliabilitas, dan (2) uji persyaratan analisis data: uji linearitas, uji normalitas, dan uji hipotesis.

\section{RESULTS AND DISCUSSION}

Adapun deskripsi dari hasil dan pembahasan dari temuan penelitian sebagai berikut:

1. Hasil Belajar Peserta didik Sebelum Memanfaatkan Media Lingkungan Sebagai Sumber Belajar di Madrasah Ibtidaiyah Al-Amalul Khair Palembang

Untuk mengetahui hasil belajar peserta didik setelah melakukan proses pembelajaran, sebelum pemanfaatan media lingkungan sebagai sumber belajar di kelas III. B pada materi lingkungan sehat dan tidak sehat di Madrasah Ibtidaiyah Al-Amalul Khair Palembang. Untuk mengetahui hasil belajar sebelum pemanfaatan media lingkungan sebagai sumber belajar peneliti memberikan soal pretest berupa soal pilihan ganda sebanyak 10 soal. Dari setiap soal yang dijawab dengan mendapatkan skor 10. Skor tertinggi 100 dan skor terendah 0. Dari hasil tes yang diujikan pada peserta didik, didapat data hasil belajar peserta didik pada mata pelajaran IPA kelas III di Madrasah Ibtidaiyah Al-Amalul Khair Palembang 
sebelum pemanfaatan media lingkungan sebagai sumber belajar setelah data terkumpul, maka proses pengolahan data yaitu sebagai berikut ini:

Tabel 1. Nilai Pretest (T1) Peserta didik Sebelum Memanfaatkan Media Lingkungan Sebagai Sumber Belajar.

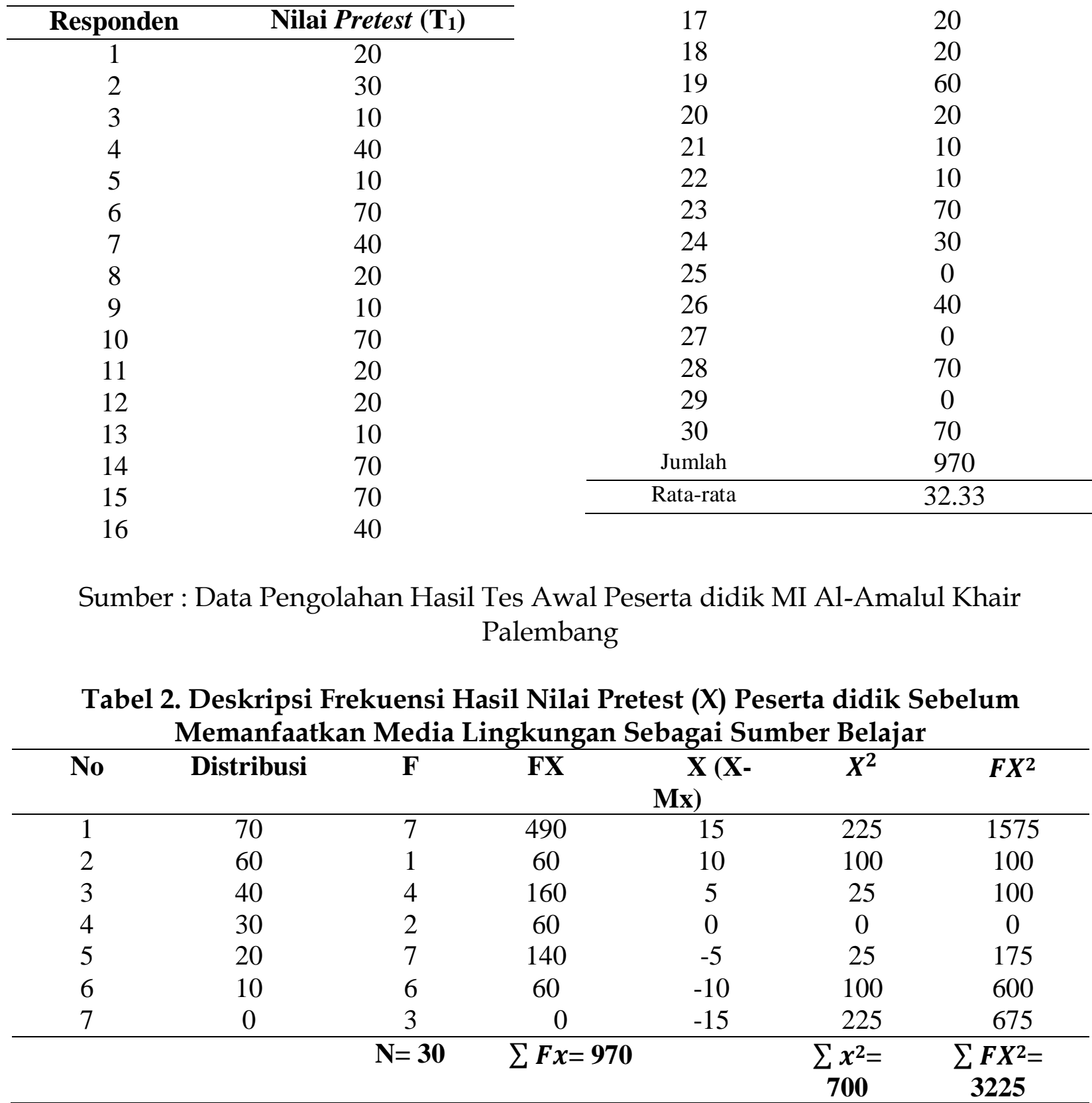

Setelah data terkumpul dan dihitung, maka jumlah seluruh nilai yang di dapatkan yaitu 970 dari 30 orang peserta didik, peserta didik yang mendapatkan nilai 0 ada 3 orang peserta didik, nilai 10 ada 6 orang peserta didik, nilai 20 ada 7 orang peserta didik, nilai 30 ada 2 orang, nilai 40 ada 4 orang peserta didik, nilai 60 ada 1 orang peserta didik, nilai 70 ada 7 orang peserta didik, dengan rata-rata 32.33 pada kelas III. B mata pelajaran IPA materi lingkungan sehat dan tidak sehat di Madrasah Ibtidaiyah Al-Amalul Khair Palembang. 
2. Hasil Belajar Peserta didik Sesudah Memanfaatkan Media Lingkungan Sebagai Sumber Belajar di Madrasah Ibtidaiyah Al-Amalul Khair Palembang

Untuk mengetahui hasil belajar peserta didik setelah melakukan proses pembelajaran, sesudah pemanfaatan media lingkungan sebagai sumber belajar di kelas III. B pada materi lingkungan sehat dan tidak sehat di Madrasah Ibtidaiyah Al-Amalul Khair Palembang. Untuk mengetahui hasil belajar sesudah pemanfaatan media lingkungan sebagai sumber belajar peneliti memberikan soal posttest berupa soal pilihan ganda sebanyak 10 soal. Dari setiap soal yang dijawab dengan mendapatkan skor 10. Skor tertinggi 100 dan skor terendah 0.

Dari hasil tes yang diujikan pada peserta didik, didapat data hasil belajar peserta didik pada mata pelajaran IPA kelas III. B di Madrasah Ibtidaiyah AlAmalul Khair Palembang sesudah pemanfaatan media lingkungan sebagai sumber belajar setelah data terkumpul, maka proses pengolahan data yaitu sebagai berikut ini:

Tabel 3. Nilai Post-test (T2) Peserta didik Sebelum Memanfaatkan Media Lingkungan Sebagai Sumber Belajar

\begin{tabular}{cccc}
\hline Responden & Nilai Post-test $\mathbf{T}_{\mathbf{2}} \mathbf{)}$ & 17 & 100 \\
\cline { 1 - 2 } 2 & 100 & 18 & 100 \\
2 & 80 & 19 & 100 \\
3 & 100 & 20 & 30 \\
4 & 100 & 21 & 90 \\
5 & 20 & 22 & 70 \\
6 & 100 & 23 & 90 \\
7 & 100 & 24 & 90 \\
8 & 100 & 25 & 60 \\
9 & 30 & 26 & 100 \\
10 & 100 & 27 & 30 \\
11 & 30 & 28 & 100 \\
12 & 50 & 29 & 40 \\
13 & 90 & 30 & 100 \\
14 & 100 & Jumlah & 2400 \\
15 & 100 & Rata-rata & 80 \\
16 & 100 & &
\end{tabular}

Sumber : Data Pengolahan Hasil Tes Akhir Peserta didik MI Al-Amalul Khair Palembang

Tabel 4. Deskripsi Frekuensi Hasil Nilai Post-test (X) Peserta didik Sesudah Memanfaatkan Media Lingkungan Sebagai Sumber Belajar

\begin{tabular}{ccccccc}
\hline No & Distribusi & $\mathbf{F}$ & $\mathbf{F Y}$ & $\begin{array}{c}\mathbf{X} \\
(\mathbf{X}-\mathbf{M x})\end{array}$ & $\boldsymbol{Y}^{\mathbf{2}}$ & $\boldsymbol{F Y}^{\mathbf{2}}$ \\
\hline 1 & 100 & 16 & 1600 & 10 & 100 & 1600 \\
2 & 90 & 4 & 360 & 5 & 25 & 100 \\
3 & 80 & 1 & 80 & 0 & 0 & 0 \\
4 & 70 & 1 & 70 & -5 & 350 & 350 \\
5 & 60 & 1 & 60 & -10 & 600 & 600
\end{tabular}




\begin{tabular}{ccccccc}
6 & 50 & 1 & 50 & -15 & 750 & 750 \\
7 & 40 & 1 & 40 & -20 & 600 & 600 \\
8 & 30 & 4 & 120 & -25 & 3000 & 12000 \\
9 & 20 & 1 & 20 & -30 & 600 & 600 \\
\hline & & $\mathbf{N}=\mathbf{3 0}$ & $\sum \boldsymbol{F} \boldsymbol{x}=$ & & $\sum \boldsymbol{y}^{2}=$ & $\sum \boldsymbol{F} \boldsymbol{Y}^{2}=$ \\
& & $\mathbf{2 4 0 0}$ & & $\mathbf{6 0 2 5}$ & $\mathbf{1 6 6 0 0}$ \\
\hline
\end{tabular}

Setelah data terkumpul dan dihitung, maka jumlah seluruh nilai yang didapatkan yaitu 2400 dari 30 orang peserta didik, peserta didik yang mendapatkan nilai 20 ada 1 orang peserta didik, nilai 30 ada 4 orang peserta didik, nilai 40 ada 1 orang peserta didik, nilai 50 ada 1 orang, nilai 60 ada 1 orang peserta didik, nilai 70 ada 1 orang peserta didik, nilai 80 ada 1 orang peserta didik, nilai 90 ada 4 orang peserta didik, nilai 100 ada 16 orang peserta didik dengan rata-rata 80 pada kelas III. B mata pelajaran IPA materi lingkungan sehat dan tidak sehat di Madrasah Ibtidaiyah Al-Amalul Khair Palembang.

3. Pengaruh manfaat Media Lingkungan sebagai Sumber Belajar terhadap Hasil Belajar Mata Pelajaran IPA kelas III di MI Al- Amalul Khair Palembang

Berdasarkan analisis dari penelitian dan pembahasan menunjukan bahwa Hasil belajar peserta didik menggunakan Pemanfaatan media lingkungan sebagai sumber belajar dalam pembelajaran mata pelajaran IPA materi lingkungan sehat dan tidak sehat menunjukan bahwa terdapat pengaruh antara keduanya hal ini bisa dilihat di perhitungan statistik dihitung dengan menggunakan rumus SPSS produk moment menyatakan bahwa Ha menunjukkan terdapat pengaruh pemanfaatan media lingkungan sebagai sumber belajar terhadap hasil belajar peserta didik pada mata pelajaran IPA materi lingkungan sehat dan tidak sehat di MI Al-Amalul Khair Palembang diterima, sedangkan $\mathrm{HO}$ yang berbunyi bahwa tidak terdapat pengaruh pemanfaatan media lingkungan sebagai sumber belajar terhadap hasil belajar pada mata pelajaran IPA materi lingkungan sehat dan tidak sehat di MI Al-Amalul Khair Palembang di tolak. Karena t hitung yakni 10,617 lebih besar dari pada t tabel pada taraf $5 \%$ yakni 1,699. Hal ini disebabkan karena pembelajaran pemanfaatan media lingkungan sebagai sumber belajar lebih mampu memberikan semangat dan fokus peserta didik dalam memperhatikan penjelasan dari guru serta peserta didik mampu mengerjakan soal-soal yang di berikan oleh guru. Media lingkungan berfungsi sebagai alat bantu dalam proses pembelajaran tersebut dan dapat membantu guru dalam menjelaskan materi agar bisa dicerna dan di serap peserta didik dan juga membantu peserta didik agar lebih mudah mengerti yang di jelaskan oleh guru inilah mengapa hasil belajar peserta didik dalam proses pembelajaran mengalami perbedaan setelah digunakan pemanfaatan media lingkungan sebagai sumber belajar dalam proses pembelajaran.

Dalam proses pembelajaran dengan kehadiran pemanfaatan media lingkungan sangat membantu baik guru maupun peserta didik dalam belajar mengajar. Hal ini dibuktikan bahwasannya hasil belajar peserta didik kelas III. B di MI Al-Amalul Khair Palembang sebelum pemanfaatan media lingkungan sebagai sumber belajar dalam pembelajaran IPA termasuk dalam kategori rendah kemudian penelitian dilanjutkan dengan menghadirkan pemanfaatan media lingkungan sebagai sumber belajar dalam proses pembelajaran IPA materi 
lingkungan sehat dan tidak sehat maka hasil belajar peserta didik terbukti meningkat dan mencapai hasil yang memuaskan melalui analisis SPSS versi 16, dikatakan bahwa hasil belajar peserta didik setelah pemanfaatan media lingkungan sebagai sumber belajar dalam pembelajaran IPA materi lingkungan sehat dan tidak sehat dinyatakan termasuk dalam kategori tinggi.

Hal ini pemanfaatan media lingkungan cukup dapat dijadikan salah satu alat yang berperan penting dalam membantu guru melaksanakan tugasnya dengan mudah yakni menyampaikan isi materi pelajaran. Sedangkan untuk peserta didik pemanfaatan media lingkungan dalam pembelajaran merupakan alat bantu peserta didik dalam menyerap dan memahami isi materi pelajaran yang disampaikan oleh gurunya. Dalam pembelajaran IPA materi lingkungan sehat dan tidak sehat terlihat bahwa peserta didik yang tadinya tidak fokus dan suka bermain-main saat belajar dengan adanya pemanfaatan media lingkungan menjadi fokus dalam mengikuti pembelajaran mereka sangat mendengar dan menyiapkan diri mereka pada saat proses pembelajaran berlangsung dan pembelajaran tersebut dirasa lebih bermakna dan membekas untuk peserta didik.

a. Uji Validitas

Hasil uji validitas pretes dapat dilihat pada tabel berikut.

Tabel 5. Uji Validitas Pretest

\begin{tabular}{cccc}
\hline No & R Hitung & R Tabel & Keterangan \\
\hline 1 & 0,617 & 0,361 & Valid \\
2 & 0,411 & 0,361 & Valid \\
3 & 0,683 & 0,361 & Valid \\
4 & 0,677 & 0,361 & Valid \\
5 & 0,479 & 0,361 & Valid \\
6 & 0,648 & 0,361 & Valid \\
7 & 0,451 & 0,361 & Valid \\
8 & 0,364 & 0,361 & Valid \\
9 & 0,509 & 0,361 & Valid \\
10 & 0,470 & 0,361 & Valid \\
\hline
\end{tabular}

Berdasarkan tabel 5 tersebut diperoleh dari 30 responden dan 10 item pertanyaan pada hasil jawaban peserta didik dinyatakan valid dan dapat digunakan sebagai alat pengumpulan data berdasarkan hasil nilai $\mathrm{r}$ hitung $>$ nilai $\mathrm{r}$ tabel. Jadi dari 10 soal pertanyaan dapat dikatakan valid karena $r$ hitung lebih besar dari $r$ tabel taraf $5 \%$.

Hasil uji validitas post-tes dapat dilihat pada tabel berikut. Tabel 6. Uji Validitas Post-test

\begin{tabular}{cccc}
\hline No & R Hitung & R Tabel & Keterangan \\
\hline 1 & 0,649 & 0,361 & Valid \\
2 & 0,801 & 0,361 & Valid \\
3 & 0,648 & 0,361 & Valid \\
4 & 0,762 & 0,361 & Valid \\
5 & 0,931 & 0,361 & Valid \\
6 & 0,769 & 0,361 & Valid \\
7 & 0,527 & 0,361 & Valid
\end{tabular}




\begin{tabular}{cccc}
8 & 0,716 & 0,361 & Valid \\
9 & 0,562 & 0,361 & Valid \\
10 & 0,649 & 0,361 & Valid \\
\hline
\end{tabular}

Berdasarkan tabel 6 tersebut diperoleh dari 30 responden dan 10 item pertanyaan pada hasil jawaban peserta didik dinyatakan valid dan dapat digunakan sebagai alat pengumpulan data berdasarkan hasil nilai $r$ hitung $>$ nilai $r$ tabel. Jadi dari 10 soal pertanyaan dapat dikatakan valid karena $r$ hitung lebih besar dari $r$ tabel taraf $5 \%$.

b. Uji Reliabilitas

Untuk mengetahui hasil uji realibilitas pretest dapat dilihat pada tabel berikut.

Tabel 7. Hasil Uji Reliabilitas Pretest

\section{Reliability Statistics}

Cronbach's

\begin{tabular}{cr} 
Alpha & N of Items \\
\hline $.718 \quad 10$ \\
\hline
\end{tabular}

Dari analisis data pada tabel 7 tersebut dapat dilihat bahwah nilai pretest cronbach's alpha tersebut adalah 0.718. Nilai tersebut lebih besar dari dari pada 0.60 maka dapat dikatakan reliabel.

Untuk mengetahui uji reliabilitas post-test dapat dilihat pada tabel berikut.

Tabel 8. Hasil Uji Realibilitas Post-test

\begin{tabular}{|c|c|}
\hline \multicolumn{2}{|c|}{ Reliability Statistics } \\
\hline Cronbach's & \\
\hline Alpha & $\mathrm{N}$ of Items \\
\hline .88 & 10 \\
\hline
\end{tabular}

Dari analisis data pada tabel 8 tersebut dapat dilihat bahwa nilai posttest cronbach's alpha tersebut adalah 0.886. Nilai tersebut lebih besar dari dari pada 0.60 maka dapat dikatakan reliabel.

c. Uji Normalitas

Data ditafsirkan normal jika $\mathrm{r}$ hitung $>0,05$. jika $\mathrm{r}$ hitung $<0,05$ maka data ditafsirkan tidak normal. Kolmogrove smirnov adalah bagian untuk melihat normalitas data. Ditunjukkan pada tabel di bawah yang menunjukkan bahwa data dari masing-masing variabel semuanya normal. 
Tabel 9. Uji Normalitas One-Sample Kolmogorov-Smirnov Test

\begin{tabular}{|c|c|c|}
\hline & & $\begin{array}{c}\text { Unstandardiz } \\
\text { ed Residual }\end{array}$ \\
\hline \multicolumn{2}{|l|}{$\mathrm{N}$} & 30 \\
\hline \multirow[t]{2}{*}{ Normal Parameters ${ }^{\mathrm{a}}$} & Mean & .0000000 \\
\hline & Std. Deviation & 23.08924443 \\
\hline \multirow{3}{*}{$\begin{array}{l}\text { Most Extreme } \\
\text { Differences }\end{array}$} & Absolute & .149 \\
\hline & Positive & .078 \\
\hline & Negative & -.149 \\
\hline \multicolumn{2}{|c|}{ Kolmogorov-Smirnov Z } & .816 \\
\hline \multicolumn{2}{|l|}{ Asymp. Sig. (2-tailed) } & .519 \\
\hline \multicolumn{3}{|c|}{ a. Test distribution is Normal. } \\
\hline
\end{tabular}

Berdasarkan tabel 9 diatas diketahui bahwa taraf signifikan pretest dan post test sebesar 0,519 yang lebih besar dari 0,05 sehingga dapat dikatakan normal.

d. Uji Linearitas

Untuk melihat nilai pretest dan posttest menggunakan bantuan SPSS versi 16. Hubungan pretest dan posttest dinyatakan linear apabila signifikasi yang diperoleh lebih kecil dari 0,05 sebaliknya jika nilai signifikasi lebih besar dari 0,05 maka dinyatakan tidak linear. Dari hasil perhitungan linearitas dapat dilihat tabel berikut.

Tabel 10. Uji Linearitas

ANOVA Table

\begin{tabular}{|c|c|c|c|c|c|c|c|}
\hline & & & $\begin{array}{l}\text { Sum of } \\
\text { Squares }\end{array}$ & Df & $\begin{array}{l}\text { Mean } \\
\text { Square }\end{array}$ & $\mathrm{F}$ & Sig. \\
\hline \multirow{5}{*}{$\begin{array}{l}\quad \mathrm{P} \\
\text { osttest } \\
* \text { Pretest }\end{array}$} & Between Groups & (Combined) & 9921.429 & 6 & 1653.571 & 2.822 & .033 \\
\hline & & Linearity & 7939.717 & 1 & 7939.717 & 13.548 & .001 \\
\hline & & $\begin{array}{l}\text { Deviation } \\
\text { from } \\
\text { Linearity }\end{array}$ & 1981.712 & 5 & 396.342 & .676 & .646 \\
\hline & Within Groups & & 13478.571 & 23 & 586.025 & & \\
\hline & Total & & 23400.000 & 29 & & & \\
\hline
\end{tabular}

Berdasarkan tabel $10 \mathrm{di}$ atas diperoleh nilai sig linearity sebesar 0,001 < $\mathrm{a}=0,05$ artinya linear. 
e. Uji Paired Sampel T-Test

Uji Paired Sampel T-Test ini dimaksudkan untuk menguji pengaruh masing-masing hasil pretest dan posttest. Hasil analisis Paired Sampel T-Test sebagai berikut:

Tabel 11. Uji $t$

Paired Samples Test

\begin{tabular}{|c|c|c|c|c|c|c|c|c|}
\hline & & Pair & d Differ & nces & & & & \\
\hline & & & & $95 \% \mathrm{Cc}$ & fidence & & & \\
\hline & & Std. & $\begin{array}{l}\text { Std. } \\
\text { Error }\end{array}$ & $\begin{array}{r}\text { Interv } \\
\text { Diff }\end{array}$ & $\begin{array}{l}\text { of the } \\
\text { ence }\end{array}$ & & & \\
\hline & Mean & Deviation & Mean & Lower & Upper & $\mathrm{T}$ & Df & tailed) \\
\hline $\begin{array}{l}\text { Pair } 1 \text { pre test - } \\
\text { post test }\end{array}$ & -47.667 & 24.591 & 4.490 & -56.849 & -38.484 & -10.617 & 29 & .000 \\
\hline
\end{tabular}

Berdasarkan tabel tersebut diketahui bahwa nilai sig. (2-tailed) adalah sebesar 0,000 lebih < dari 0,05 maka H0 ditolak dan Ha diterima. Sehingga dapat disimpulkan bahwa ada pengaruh pemanfaatan media lingkungan sebagai sumber belajar terhadap hasil belajar mata pelajaran IPA kelas III di MI AlAmalul Khair Palembang. Dan $t$ hitungnya bernilai negatif sebesar -10.617. $t$ hitung disebabkan negatif dikarenakan nilai rata-rata hasil belajar pretest lebih rendah dari pada rata-rata hasil belajar posttest. Maka t hitung negatif dapat bermakna positif. Sehingga t hitung menjadi 10.617. Dengan demikian $t$ hitung 10.617 lebih besar > dari t tabel taraf 5\% yakni 1.699 sehingga dapat disimpulkan bahwa H0 ditolak dan Ha diterima. Yang berarti ada pengaruh pemanfaatan media lingkungan sebagai sumber belajar terhadap hasil belajar mata pelajaran IPA kelas III di MI Al-Amalul Khair Palembang.

Penggunaan tes " $t$ " pada penelitian ini mengasumsikan hipotesis nihil yaitu ada atau tidak ada pengaruh yang signifikan dalam pemanfaatan media lingkungan sebagai sumber belajar terhadap hasil belajar pada mata pelajaran IPA kelas III di MI Al-Amalul Khair Palembang. Adapun kriteria pengambilan keputusan uji t sebagai berikut:

1) Ha : Jika nilai probabilitas lebih besar dari 0,05, maka $\mathrm{HO}$ diterima atau Ha ditolak, ini berarti menyatakan bahwa variabel independen atau bebas tidak mempunyai pengaruh secara individual terhadap variabel dependen atau terikat.

2) H0 : Jika nilai probabilitas lebih kecil dari 0,05, maka $\mathrm{H} 0$ ditolak atau Ha diterima, ini berarti menyatakan bahwa variabel independen atau bebas mempunyai pengaruh secara individual terhadap variabel dependen terikat.

Berdasarkan hasil penelitian menunjukkan bahwa terdapat pengaruh antara keduanya hal ini dapat dilihat dari perhitungan statistik dimana Ha diterima dan H0 ditolak karena nilai signifikan sebesar 0,000 < 0,05 dan t hitung yakni 10.617 lebih besar dari $\mathrm{t}$ tabel pada taraf $5 \%$ yakni 1.699 dengan demikian bahwa H0 ditolak dan Ha diterima, sehingga dapat disimpulkan bahwa ada pengaruh yang signifikan antara pemanfaatan media lingkungan sebagai sumber belajar 
mata pelajaran IPA terhadap hasil belajar peserta didik kelas III B di MI AlAmalul Khair Palembang. Hal ini dapat dilihat dari nilai tes soal mereka meningkat atau lebih baik dari pada sebelum pemanfaatan media lingkungan sebagai sumber belajar. Sehingga pembelajaran dengan pemanfaatan media lingkungan dapat digunakan sebagai salah satu alternatif dalam pelaksanaan pembelajaran terhadap hasil belajar peserta didik.

\section{CONCLUSIONS}

Berdasarkan hasil analisis data menunjukkan bahwa nilai sig sebesar 0,000 lebih < dari 0,05 dan $\mathrm{t}$ hitungnya sebesar 10.617 lebih besar dari $\mathrm{t}$ tabel taraf 5\% yakni 1.699. Hasil analisis data ini menunjukkan bahwa Ho ditolak dan Ha diterima, yang berarti terdapat pengaruh antara pretest dan post test. Sehingga dapat disimpulkan bahwa terdapat pengaruh pemanfaatan media lingkungan sebagai sumber belajar terhadap hasil belajar mata pelajaran IPA kelas III di MI Al-Amalul Khair Palembang.

\section{ACKNOWLEDGEMENTS (OPTIONAL)}

Penulis mengucapkan terima kasih kepada Islamic Statate University of Raden Fatah Palembang, Indonesia atas dukungan dan bantuan dalam menyelesaikan penelitian ini.

\section{REFERENCES}

Daryanto, 2010, Belajar dan Mengajar, Bandung: Yrama Widya.

Fatoni, dkk., 2012, Buku Ajar Ilmu Pengetahuan Alam Untuk SD/MI, Solo: CV. Sindunata,

Hendarwati, Endah. (2013). Pengaruh Pemanfaatan Lingkungan sebagai Sumber Belajar Melalui Metode Inkuiri terhadap Hasil Belajar Siswa SDN 1 Sribit Delanggu Pada Mata Pelajaran IPS . Jurnal Pedagogia, 2(1), 59-70.

Istiani, Rina Munawar., Amin Retnoningsih. (2015). Pemanfaatan Lingkungan Sekolah sebagai Sumber Belajar Menggunakan Metode Post to Post pada Materi Klasifikasi Makhluk Hidup. Journal of Biology Education, 4(1), 70-80.

Khanifah, Sri., Krispinus Kedati Pukan, \& Sri Sukaesih. (2012). Pemanfaatan Lingkungan Sekolah sebagai Sumber Belajar untuk Meningkatkan Hasil Belajar Siswa. Journal of Biology Education, 1(1), 66-73.

Kokom Komalasari, 2010, Pembelajaran Konstektual, Bandung: Refika Aditama.

Mahkota, Silvia Prana., Tri Jalmo, E Berti Yolida. (2014). Pengaruh Penggunaan Lingkungan Sekitar Sekolah Sebagai Sumber Belajar Terhadap Kemampuan Berpikir Kritis, Jurnal Bioterdidik: Wahana Ekspresi Ilmiah. 2(3).

Ramawati, Isye. (2016). Pemanfaatan Lingkungan Sekitar sebagai Sumber Pembelajaran untuk Meningkatkan Kemampuan Berpikir Kritis. Jurnal Geografi Gea. 16(1), 66-87

Rasiman, I., Taseman, I Kartikasari, M W Laili, Muzdalifa, \& S Maryam. (2020). Pemanfaatan Media Peta dalam Pembelajaran IPS Kelas V di MI Al-Muniroh 1 Ujung Pangkah. JIEES: Journal of Islamic Education at Elementary School, 1(1), 1-9. 
Rita Mariyana, dkk., 2010, Pengelolaan Lingkungan Belajar, Jakarta: Prenada Media Group.

Sangidun, 2010, Kampus Kawasan Lingkungan, Yogyakarta: SAKA.

Syaiful Bahri Djamarah dan Aswan Zain, 1997. Strategi Belajar Mengajar, Jakarta: Rineka Cipta.

Taseman, Iman Rasiman, Arumi Puji Lestari, Atik Anturichana, Hanyfa Maulidiyah, H.

H. (2020). IMPLEMENTASI EVALUASI SOAL PEMBELAJARAN IPS THE IMPLEMENTATION OF LEARNING EVALUATION ON SOCIAL STUDIES BASED ON 2013 CURRICULUM AT MI ASSYAFI' IYAH. AULADUNA: Jurnal Pendidikan Dasar Islam, 7(1), 74-80

Taseman. (2020). Pemanfaatan Media Visual Pada Pembelajaran IPS Di MI Darul Mutaallimin Sidoarjo. BADA' A: Jurnal Ilmiah Pendidikan Dasar, 2(1), 86-97.

Usman Samatowa, 2007, Pembelajaran IPA di Sekolah Dasar, Jakarta: Pustaka Indonesia Press.

Usman Samatowa, 2011, Pembelajaran IPA di Sekolah Dasar, Jakarta: Indeks.

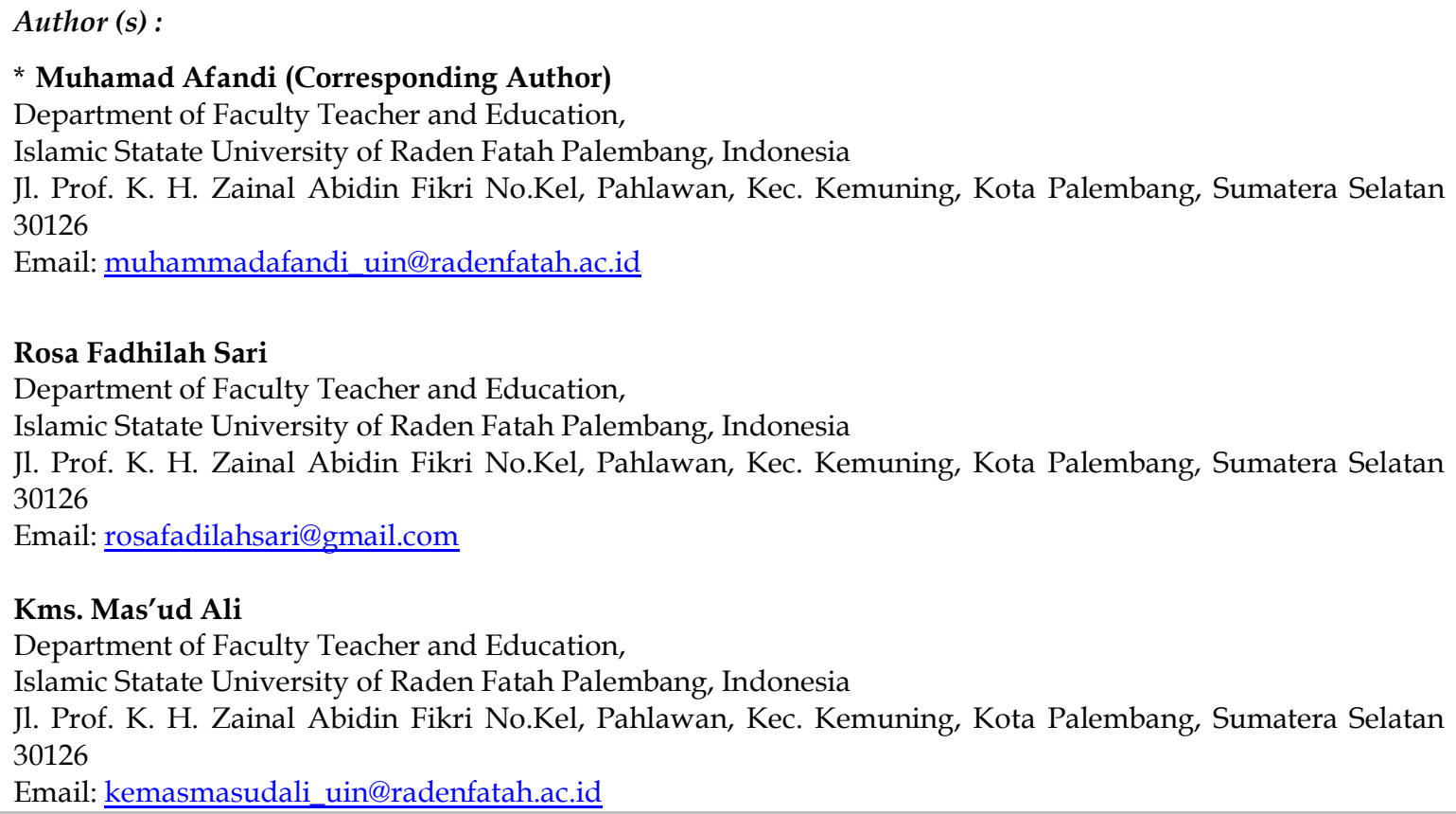

